\title{
Epoprostenol (PGI2, Prostacyclin) During High-Risk Hemodialysis: Preventing Further Bleeding Complications
}

\author{
Richard D. Swartz, MD, Walter Flamenbaum, MD, Alan Dubrow, MD, \\ Jane C. Hall, MS, James W. Crow, PhD, Alan Cato, MD
}

\begin{abstract}
The frequency of hemodialysis-associated hemorrhage was studied prospectively in two successive, parallel, heparin-controlled studies using epoprostenol (PGI2; average dose, $4.1 \mathrm{ng} / \mathrm{kg} \cdot \mathrm{min}$ ) as the sole antithrombotic agent. Sixty-three patients with active or recently active bleeding underwent 163 hemodialysis treatments in each of which prospective bleeding risk was assessed. PGI2 was associated with up to $50 \%$ overall reduction in the frequency of bleeding, particularly in the highest risk circumstances. PGI2 also allowed successful completion of the full, prospectively prescribed hemodialysis time in the most treatments ( $82 \%$ versus $93 \%$ with heparin). Furthermore, the efficiency of hemodialysis using PGI2, as indicated by the reduction in concentration of blood urea nitrogen and serum creatinine, was equal to that using heparin, even though there was a tendency toward modest reduction in residual volume of the hollow fiber dialyzer and slightly more frequent early termination of treatment from dialyzer clotting with PGI2. No severe vasodilatory side effects of PGI2 were observed during these studies. Hypotension was equally frequent during hemodialysis with heparin as with PGI2. The current results suggest that PGI2 should be considered as a substitute for heparin during high-risk hemodialysis because PGI2 may reduce the incidence of dialysis-associated bleeding without severe adverse side effects.
\end{abstract}

$\mathbf{H}^{\mathrm{e}}$ emodialysis may improve the qualitative platelet abnormality of uremia and reduce the bleeding tendency in patients with acute or chronic renal failure. However, the requirement for heparin to prevent extracorporeal clotting during hemodialysis may actually increase the risk of new or worsened bleeding among patients already at higher risk. As a result, there is considerable interest in developing methods, such as controlled dosing of heparin, ${ }^{1-5}$ to minimize the danger to the bleeding patient. When analyzed rigorously and systematically, ${ }^{8}$ regional heparinization with protamine ${ }^{6.7}$ has proven

From the Division of Nephrology and Department of Medicine, University of Michigan Medical Center (Dr. Swartz), Ann Arbor, Michigan; the Division of Nephrology and Hypertension, Beth Israel Medical Center (Drs. Flamenbaum and Dubrow), New York, New York; and Wellcome Research Laboratories (Drs. Hall, Crow, and Cato), Research Triangle Park, North Carolina. Address for reprints: Richard D. Swartz, MD, Division of Nephrology, Department of Internal Medicine, 3914 Taubman Center (Box 0364), University of Michigan Medical Center, Ann Arbor, MI 48109. cumbersome to perform and ineffective compared with low-dose heparin in preventing bleeding complications. Regional anticoagulation with citrate ${ }^{9}$ is also cumbersome and is not yet widely used or accepted. Hemodialysis without anticoagulation ${ }^{10-12}$ and hemodialysis with intermittent saline washout only ${ }^{13}$ have also been advocated.

Epoprostenol (prostacyclin, PGI2) is a short-acting inhibitor of platelet aggregation at doses below those causing marked vasodilatation. ${ }^{14-17}$ In vitro and in vivo studies show that platelet loss during extracorporeal circulation can be reduced using PGI2. ${ }^{18-22}$ Cardiopulmonary bypass ${ }^{19.20}$ and hemodialysis, ${ }^{21-23}$ among extracorporeal circulatory procedures, have been both feasible and effective with PGI2 and reduce extracorporeal platelet loss with few serious adverse effects. As a short-acting agent, PGI2 may prove useful during hemodialysis not only in preventing clotting of the extracorporeal circuit but also in reducing bleeding in patients at risk. ${ }^{24-27}$

The current parallel, heparin-controlled study compares the results of hemodialysis with PGI2 to 
those with tightly monitored, low-dose heparin for patients with increased bleeding risk.

\section{METHODS}

The experience described here includes two controlled studies, the first (study A), a rigorous pilot performed at two major centers between December 1982 and November 1983 and the second (study B), a wider study performed at six centers between December 1983 and March 1984. The only differences between the two studies were the more intense evaluation for drug effect and side effects in study A, and the maximum duration of six hemodialysis treatments in the initial study (study A) versus three treatments in study B.

\section{Subjects}

All patients were between the ages of 18 and 80 years, needed hemodialysis for complications of acute or chronic renal failure, and were at increased risk for bleeding at the time of hemodialysis. Subjects were identified 24 hours or more before entry into the study. Informed consent was obtained consistent with the guidelines of the institutional review boards of the participating institutions. Exclusion criteria included only pregnancy and severe cardiovascular instability.

\section{Bleeding Risk}

The recognition of bleeding risk was based on the clinical judgment of participating physicians at each center. The site of bleeding risk was specifically identified before entry into the study, although change in site of risk was assessed for each subsequent hemodialysis as well.

The degree of bleeding risk was categorized on the basis of the hemorrhagic risk just before initiation of each hemodialysis. Four risk categories were identified within 24 hours before each treatment as previously described ${ }^{8}$ : very high, actively bleeding at the time of hemodialysis; high, active bleeding or new surgical wound within 3 days of hemodialysis; moderate, active bleeding or new surgical wound within 3 to 7 days of hemodialysis; and low, no active bleeding or wound within 7 days of hemodialysis.

\section{Patient Assignment}

Patients entered the study chronologically and consecutively. Within each participating center patients were randomized either to heparin or to PGI2 within each initial risk category on the day of screening (usually within 24 hours of the first study hemodialysis).

All subjects then underwent a course of hemodialysis using the assigned agent (up to six hemodialyses in the first study and up to three hemodialyses in the second study). Again, degree and site of risk were reassessed for the purposes of analysis before each hemodialysis, although the initial random assignment was not changed. A course of hemodialysis for a given patient was terminated at the discretion of participating physicians, based on the occurrence of (1) clinical complications related or unrelated to the study agent, (2) mechanical complications with hemodialysis itself, or (3) no further need for acute hemodialysis during the study course.

\section{Hemodialysis Specifications}

All hemodialyses were carried out using high sodium, bicarbonate, single-pass dialysate systems. Hollow fiber dialyzers of the cellulose acetate or cuprophane type were used in almost all instances. Occasional dialysis was performed using parallel plate devices at the discretion of the investigators. Vascular access was that chosen by, and available to, the physicians, and included two-needle fistula or graft access, single-needle central venous access and double-lumen central venous access.

\section{Drug Protocols}

For patients assigned to heparin, a low-dose protocol was based on loading doses below $20 \mathrm{U} / \mathrm{kg}$ and maintenance infusion rates below $20 \mathrm{U} / \mathrm{kg} \cdot \mathrm{hr}$. Patients were monitored and infusion rates were adjusted to maintain the activated clotting time or the thrombin clotting time at a maximum of 1.5 to 2 times the baseline value.

PGI2 in glycine buffer (synthesized by The Upjohn Company, Kalamazoo, MI, and formulated by Wellcome Foundation Limited, Research Triangle Park, NC) was administered as an infusion at 4 $\mathrm{ng} / \mathrm{kg} / \mathrm{min}$ given for 10 minutes before hemodialysis intravenously through the venous dialysis access and throughout hemodialysis into the hemodialysis circuit between the blood pump and the dialyzer. Infusion rates were adjusted downward for side effects or upward toward $8 \mathrm{ng} / \mathrm{kg} / \mathrm{min}$ for evidence of early clotting in the extracorporeal circuit. Doses were based on previously described platelet inhibition studies. ${ }^{18-27}$

\section{Study Assessments}

Hemodialysis efficiency was assessed on the basis of completion of prescribed treatment without me- 
TABLE I

Patient Characteristics

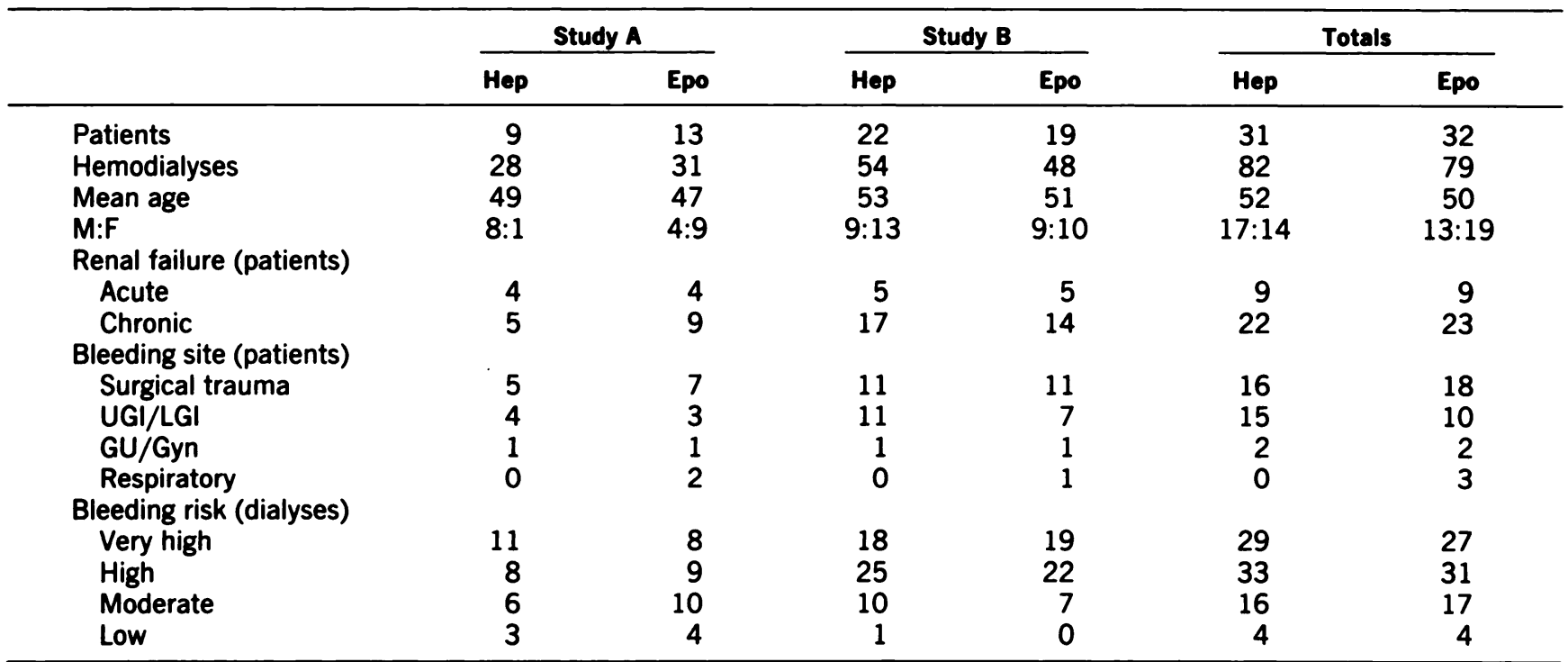

Hep: heparin; Epo: epoprostenol.

Some patients had more than one bleeding site.

Bleeding risk is that at the time of each dialysis.

chanical or clinical complication and solute removal indicated by comparison of concentrations of blood urea nitrogen and serum creatinine before hemodialysis with those after hemodialysis. Direct measurement of clearance and ultrafiltration were undertaken but were cumbersome and difficult to standardize because neither blood flow rates nor dialyzer type and size were controlled. Therefore, clearance and ultrafiltration data are not reported here.

Dialyzer clotting was assessed on the basis of residual dialyzer volume after treatment as measured by air washout technique and the frequency of early termination of treatment because of clotting complications.

Hemorrhage was determined during the first 24 hours after initiation of hemodialysis by direct evidence for active bleeding at the visible primary site of risk, as well as indirect evidence for bleeding on the basis of change in serial hematocrit determinations. Definite bleeding was considered to have occurred when there was reduction in hematocrit of 3 vol \% or more not explained by positive fluid balance or by infusion of hyperoncotic or hyperosmotic agents (albumin, plasma, mannitol, etc.) or when failure of hematocrit to increase in the face of transfusion was unexplained by similar factors. Hemolysis was considered on clinical grounds in these assessments but was seldom identified as an important consideration.

Signs and symptoms during hemodialysis were recorded, graded in severity, and assessed according to direct or indirect relation to the pharmacologic agent, heparin, or PGI2 used during treatment.

\section{Statistical Methods}

The Student's $t$ test was used to compare observed mean values between groups, and the chi-square test to compare the frequency of observed results between groups.

\section{RESULTS}

During the course of the two controlled studies described here, 63 patients underwent a total of 161 hemodialyses. Table I describes the clinical characteristics of the patients studied, showing the comparability of patients dialyzed using each study agent. Bleeding sites are listed as those on the day of the first hemodialysis. The frequency of bleeding risk is listed as the number of total hemodialyses in which bleeding occurred for each risk category.

Hemodialysis efficiency was determined by comparison of blood urea nitrogen and serum creatinine concentration values taken before hemodialysis to 
TABLE II

Dialysis Efficiency as Indicated by Reduction in Solute Concentration During Dialysis

\begin{tabular}{|c|c|c|c|c|c|c|}
\hline & \multicolumn{2}{|c|}{ Study A } & \multicolumn{2}{|c|}{ Study B } & \multicolumn{2}{|c|}{ Totals } \\
\hline & Hep & Epo & Hep & Epo & Hep & Epo \\
\hline $\begin{array}{l}\text { No. (hemodialyses) } \\
\text { Blood urea nitrogen }\end{array}$ & 23 & 30 & 52 & 44 & 75 & 74 \\
\hline $\begin{array}{l}\text { Mean } \\
\text { SD }\end{array}$ & $\begin{array}{r}1.58 \\
.26\end{array}$ & $\begin{array}{r}1.71 \\
.33\end{array}$ & $\begin{array}{r}2.30 \\
.69\end{array}$ & $\begin{array}{r}2.06 \\
.62\end{array}$ & $\begin{array}{r}2.15 \\
.75\end{array}$ & $\begin{array}{r}1.92 \\
.55\end{array}$ \\
\hline Creatinine & & & & & & \\
\hline $\begin{array}{l}\text { Mean } \\
\text { SD }\end{array}$ & $\begin{array}{r}1.48 \\
.52\end{array}$ & $\begin{array}{r}1.61 \\
.42\end{array}$ & $\begin{array}{r}1.95 \\
.48\end{array}$ & $\begin{array}{r}1.84 \\
.44\end{array}$ & $\begin{array}{r}1.81 \\
.53\end{array}$ & $\begin{array}{r}1.75 \\
.45\end{array}$ \\
\hline $\begin{array}{l}\text { Ratio of values measured befo } \\
\text { (post), irrespective of dialyzer ty }\end{array}$ & $\begin{array}{l}\text { lysis (pre) } \\
\text { flow rate. }\end{array}$ & $\begin{array}{l}\text { r hemodia } \\
s \text { between }\end{array}$ & $\begin{array}{l}\text { and Epo } \mathrm{W} \\
=\text { epopros }\end{array}$ & nificant in & own in this & $=$ hepar \\
\hline
\end{tabular}

those taken after hemodialysis, where available. Table II shows that the ratio of pretreatment values to posttreatment values were not different comparing heparin with PGI2 for either study or for all hemodialyses.

Dialyzer clotting as indicated by residual dialyzer volume was determined successfully in most of the hemodialyses, and results are shown in Table III. Values of mean posttreatment dialyzer volume tended to be somewhat lower with PGI2 than with heparin, although this difference was not statistically significant and was not reflected in significantly reduced solute clearance. Reduction in dialyzer volume by $20 \%$ (post / pre ratio below .80) and $50 \%$ (post/pre ratio below .50), respectively, were more frequent with PGI2 than with heparin. Finally, premature termination of hemodialysis because of clotting in the extracorporeal system (needles, lines, traps, dialyzer) was also statistically more frequent with PGI2 during study B and overall. Such clotting complications resulted in dropout from the study by three patients treated with PGI2 but did not eventuate in other serious complications.

Frequency of bleeding complications was assessed in the 24 hours after initiation of hemodialysis on the basis of detectable blood loss both for each individual hemodialysis, as well as for the total course of each patient. Table IV shows that the incidence of bleeding complications per dialysis with heparin was greater than that with PGI2 overall. Bleeding

\section{TABLE III}

\begin{tabular}{|c|c|c|c|c|c|c|}
\hline \multicolumn{7}{|c|}{ Indicators of Dialyzer Clotting } \\
\hline & \multicolumn{2}{|c|}{ Study A } & \multicolumn{2}{|c|}{ Study B } & \multicolumn{2}{|c|}{ Totals } \\
\hline & Hep & Epo & Hep & Epo & Hep & Epo \\
\hline \multicolumn{7}{|l|}{$\begin{array}{l}\text { No. (hemodialyses) } \\
\text { Residual dialyzer volume } \\
\text { Mean }\end{array}$} \\
\hline $\begin{array}{l}\text { Mean } \\
\text { SD } \\
\text { Residual dialyzer volume }\end{array}$ & $\begin{array}{l}.69 \\
.24\end{array}$ & $\begin{array}{l}.56 \\
.23\end{array}$ & $\begin{array}{l}.68 \\
.22\end{array}$ & $\begin{array}{l}.52 \\
.29\end{array}$ & $\begin{array}{l}.65 \\
.22\end{array}$ & $\begin{array}{l}.54 \\
.21\end{array}$ \\
\hline $\begin{array}{l}\text { Below } .80 \\
\text { Below } .50\end{array}$ & $\begin{array}{l}63 \% \\
33 \%\end{array}$ & $\begin{array}{l}79 \% \\
38 \%\end{array}$ & $\begin{array}{l}68 \% \\
20 \% *\end{array}$ & $\begin{array}{l}84 \% \\
41 \%\end{array}$ & $\begin{array}{l}66 \% * \\
25 \%+\end{array}$ & $\begin{array}{l}82 \% \\
39 \%\end{array}$ \\
\hline $\begin{array}{l}\text { Premature termination } \\
\text { or hemodialysis }\end{array}$ & $11 \%$ & $13 \%$ & $4 \% \ddagger$ & $23 \%$ & $6 \% \ddagger$ & $19 \%$ \\
\hline \multicolumn{3}{|c|}{$\begin{array}{l}-P<.05 \text {. (chi-square test). } \\
\dagger P<.10 \text {. (chi-square test). } \\
\mp P<.02 \text {. (chi-square test). } \\
\text { Residual dialyzer volume expressed as ratio of postdialysis volume to predi- } \\
\text { alysis volume. }\end{array}$} & \multicolumn{4}{|c|}{$\begin{array}{l}\text { Below . } 80 \text { and below . } 50 \text { denote postdialysis volume less than } 80 \% \text { and } 50 \% \text {, } \\
\text { respectively, of predialysis volume. Values are expressed as percent of available } \\
\text { observations. } \\
\text { Premature termination of dialysis due to clotting complication. } \\
\text { Hep = heparin; Epo = epoprostenol. }\end{array}$} \\
\hline
\end{tabular}


TABLE IV

Frequency of Bleeding Complications Among Risk Groups

\begin{tabular}{|c|c|c|c|c|c|c|}
\hline & \multicolumn{2}{|c|}{ Study A } & \multicolumn{2}{|c|}{ Study B } & \multicolumn{2}{|c|}{ Totals } \\
\hline & $\begin{array}{l}\text { Hep } \\
(\%)\end{array}$ & $\begin{array}{l}\text { Epo } \\
\text { (\%) }\end{array}$ & $\begin{array}{l}\text { Hep } \\
(\%)\end{array}$ & $\begin{array}{l}\text { Epo } \\
\text { (\%) }\end{array}$ & $\begin{array}{l}\text { Hep } \\
\text { (\%) }\end{array}$ & $\begin{array}{l}\text { Epo } \\
\text { (\%) }\end{array}$ \\
\hline \multicolumn{7}{|l|}{ Per hemodialysis* } \\
\hline Total & $50^{\circ}$ & 16 & 37 & 29 & $41^{\circ}$ & 24 \\
\hline $\begin{array}{l}\text { Very high risk } \\
\text { High risk } \\
\text { Very high and high risk } \\
\text { Moderate and low risk }\end{array}$ & $\begin{array}{l}100^{a} \\
13 \\
63^{b} \\
22\end{array}$ & $\begin{array}{r}63 \\
0 \\
29 \\
0\end{array}$ & $\begin{array}{l}78^{d} \\
24 \\
47 \\
0\end{array}$ & $\begin{array}{r}53 \\
18 \\
34 \\
0\end{array}$ & $\begin{array}{l}86^{a} \\
21 \\
52^{c} \\
10\end{array}$ & $\begin{array}{r}56 \\
13 \\
33 \\
0\end{array}$ \\
\hline $\begin{array}{l}\text { First hemodialysis } \\
\text { First }+ \text { second hemodialysis }\end{array}$ & $\begin{array}{l}56 \\
47^{c}\end{array}$ & $\begin{array}{l}25 \\
18\end{array}$ & $\begin{array}{l}65^{b} \\
44\end{array}$ & $\begin{array}{l}26 \\
31\end{array}$ & $\begin{array}{l}63^{\circ} \\
45^{\circ}\end{array}$ & $\begin{array}{l}26 \\
26\end{array}$ \\
\hline \multicolumn{7}{|l|}{ Per patient $\dagger$} \\
\hline $\begin{array}{l}\text { Total } \\
\text { Persisting bleeding risk }\end{array}$ & $\begin{array}{l}67^{d} \\
56^{c}\end{array}$ & $\begin{array}{l}31 \\
10\end{array}$ & $\begin{array}{l}64 \\
52\end{array}$ & $\begin{array}{l}47 \\
44\end{array}$ & $\begin{array}{l}65^{c} \\
53^{d}\end{array}$ & $\begin{array}{l}41 \\
31\end{array}$ \\
\hline \multicolumn{3}{|c|}{$\begin{array}{l}\text { - Frequency of bleeding expressed as percent incidence among total hemo- } \\
\text { dialyses observed. } \\
\text { t Frequency of bleeding expressed as percent incidence among total patients } \\
\text { studied. } \\
\text { Hep }=\text { heparin; Epo = epoprostenol. }\end{array}$} & $\begin{array}{l}01 \text { (chi-s } \\
02 \text { (chi-s } \\
05 \text { (chi-s } \\
10 \text { (chi-s }\end{array}$ & & & \\
\hline
\end{tabular}

was also more frequent among the higher risk groups, particularly the groups with bleeding that was active ( $\mathrm{VH}$, very high risk) or recent $(\mathrm{H}$, high risk), and among all first-dialysis treatments or all first and second hemodialysis treatments combined. Furthermore, the total number of patient courses complicated by hemodialysis-associated bleeding, as well as the number of patient courses in which bleeding risk persisted, as marked by either (1) failure of bleeding risk to improve over time because of continued or renewed bleeding or (2) study termination because of bleeding complication, also tended to be higher with heparin. Dropout from the study because of severe bleeding requiring some interruption of the course of hemodialysis and / or acute intervention, such as surgery, occurred during seven courses of hemodialysis with heparin and during only one course with PGI2.

Severity of bleeding was also evaluated during the 24 hours after initiation of hemodialysis, on the basis of quantitative assessment of hematocrit reduction relative to transfusion and parenteral fluid requirement. Among the 34 patients treated with heparin in whom bleeding complications occurred, this bleeding was judged to be mild (hematocrit change 3 vol $\%$ or less without transfusion) in 6 of 34 instances, moderate (requiring transfusion but with hematocrit change 5 vol \% or less) in 17 of 34 instances, and severe (hematocrit change above 5 vol \% with or without transfusion) in 11 of 34 instances. Among the 19 patients treated with PGI2 in whom bleeding complications occurred, this bleeding was judged to be mild in 8 of 19, moderate in 5 of 19, and severe in 6 of 19 instances. Although there was a tendency toward fewer severe episodes with PGI2, these distributions of severity were not statistically different.

Total doses of heparin averaged 55.8 U/ kg during hemodialysis in both studies, ranging from 13.5 $\mathrm{U} / \mathrm{kg}$ to $104.4 \mathrm{U} / \mathrm{kg}$, and heparin doses did not differ between risk groups. Furthermore, heparin doses did not differ in hemodialyses complicated by bleeding. Total PGI2 doses averaged $4.1 \mathrm{ng} / \mathrm{kg} \cdot \mathrm{min}$ during hemodialysis in both studies, ranging from 0.5 to $8.6 \mathrm{ng} / \mathrm{kg} \cdot \mathrm{min}$. PGI2 doses did not differ statistically between risk groups, and PGI2 doses also did not differ in hemodialyses associated with bleeding. Finally, neither heparin, PGI2 doses, nor predialysis hematocrit level correlated with clotting complications as indicated by reduction in posttreatment dialyzer volume.

The incidence of adverse drug effects among the study dialyses is summarized in Table V. Although the incidence of nausea and vomiting, flushing, or headache was somewhat higher with PGI2, these side effects were uniformly mild or moderate in degree, responded to reduction in PGI2 dose and/or conservative intervention such as saline or position change, and did not result in termination of hemodialysis in any instances. Overall, the incidence of mild or severe hypotension was not higher with 
TABLE V

\begin{tabular}{|c|c|c|c|c|c|c|}
\hline \multicolumn{7}{|c|}{ Adverse Reactions During Hemodialysis } \\
\hline \multirow[b]{2}{*}{ Adverse Reaction } & \multicolumn{2}{|c|}{ Study A } & \multicolumn{2}{|c|}{ Study B } & \multicolumn{2}{|c|}{ Totals } \\
\hline & Hep & Epo & Hep & Epo & Hep & Epo \\
\hline $\begin{array}{l}\text { No. patients } \\
\text { Hypotension } \\
\text { Chest pain } \\
\text { Abdominal pain, nausea } \\
\text { Headach } \\
\text { Flushing }\end{array}$ & $\begin{array}{l}28 \\
15(1) \\
1 \\
1(1) \\
0 \\
0\end{array}$ & $\begin{array}{l}33 \\
13(1) \\
0 \\
5 \\
6 \\
2\end{array}$ & $\begin{array}{l}55 \\
24(1) \\
1(1) \\
1 \\
0 \\
0\end{array}$ & $\begin{array}{l}48 \\
20(2) \\
2 \\
2 \\
5 \\
4\end{array}$ & $\begin{array}{l}83 \\
39(2) \\
2(1) \\
2(1) \\
0 \\
0\end{array}$ & $\begin{array}{c}81 \\
33(3) \\
2 \\
7 \\
11 \\
6\end{array}$ \\
\hline \multicolumn{7}{|c|}{$\begin{array}{l}\text { Hep }=\text { heparin; Epo }=\text { epoprostenol. Number of adverse reactions expressed } \\
\text { as total number of reactions (number of serious reactions). Other adverse reac. } \\
\text { tions such as arrhythmia, seizure, or myocardial ischemia were not observed }\end{array}$} \\
\hline
\end{tabular}

PGI2. One epidose of severe hypotension with PGI2 resulted from malfunction of the drug infusion pump and inadvertent infusion of a large drug dose; however, discontinuation of infusion reversed the episode successfully and the patient was withdrawn from the study.

\section{DISCUSSION}

Hemorrhage remains a serious complication not only of uremia but also of the hemodialysis procedure. Numerous reports document the incidence of unexpected bleeding at various sites in hemodialysis patients, including the central nervous system, ${ }^{28}$ retroperitoneum, ${ }^{29}$ mediastinum and pericardium, ${ }^{30,31}$ eye, ${ }^{32}$ kidney, ${ }^{33}$ and liver. ${ }^{34}$ These unexpected bleeding complications are observed in addition to more predictable bleeding from common sites, such as the gastrointestinal tract and surgical or traumatic wounds. ${ }^{35-39}$ Furthermore, platelet losses during hemodialysis may aggravate the already high bleeding risk. ${ }^{40}$

To prevent further hemorrhage in the hemodialysis patient already bleeding or at high risk, the degree of systemic anticoagulation must be limited during the extracorporeal circulation. Hemodialysis with low-dose heparinization and hemodialysis without anticoagulation are the most widely accepted methods, although it is documented by rigorous follow-up that bleeding may continue with lowdose heparinization. ${ }^{5}$ Regionalized extracorporeal anticoagulation procedures have proven cumbersome to perform and monitor, with heparin/protamine proving no more effective than low-dose heparin in preventing hemorrhage ${ }^{8.41}$ and with citrate / calcium not widely tested or accepted. Heparin impregnation of hemodialysis surfaces, ${ }^{42-44}$ other nonthrombogenic materials, ${ }^{45,46}$ and heparinase devices in the extracorporeal circuit ${ }^{47}$ have been described but unavailable for clinical use. Finally, peritoneal dialysis completely obviates the use of anticoagulant agents when this method can be used in the patient with increased bleeding risk.

The results of the current study suggest that PGI2, a short-acting agent that inhibits platelet aggregation, can routinely prevent extracorporeal clotting and allow hemodialysis equally efficient to that with low-dose heparin. More important, when compared with low-dose heparin in patients at increased risk, hemodialysis with PGI2 may reduce the frequency of associated hemorrhage and promote resolution of the course of bleeding during successive hemodialysis treatments. Finally, although there is a tendency to increased dialyzer clotting with PGI2, the average reduction of blood urea nitrogen and serum creatinine concentrations and the incidence of adverse effects compare favorably with hemodialysis with heparin.

The assessment of bleeding complications during and immediately after hemodialysis is difficult. In many instances the subjective assessment by the clinician does not correspond to blood loss quantifiable by changes in hematologic parameters. Careful and intensive follow-up, not only for visible evidence of bleeding but also for reduction in RBC indicators that signal bleeding complications, is essential for any study evaluating hemorrhage in acutely ill patients. Unfortunately, few studies of bleeding in the hemodialysis patient present such information, making comparison with the current study difficult. The incidence of bleeding reported in a controlled trial of regional heparinization, ${ }^{8}$ with low-dose heparin, ${ }^{5}$ and in studies of acute hemodialysis ${ }^{6,39}$ are comparable in magnitude to that reported here, and 
confirm the trend toward the improvement observed with PGI2 use.

The objective assessment of severity when bleeding occurs is even more difficult than assessment of bleeding frequency. Subjectivity confounds even the quantitation of hematocrit change, because decisions to administer blood or other volume expanders are clinical judgments based on many factors in addition to bleeding. However, even though analysis of bleeding severity is less objective than analysis of bleeding frequency, the data reported here suggest that moderate and severe bleeding may be reduced in frequency with PGI2.

There has been some concern that the antiaggregating effect of PGI2 may be sufficiently prolonged to negate the advantage of PGI2 for hemodialysis. ${ }^{48}$ However, several studies have shown that dose-related platelet inhibition often lasts fewer than 5 or 10 minutes at doses below $5 \mathrm{ng} / \mathrm{kg} \cdot \mathrm{min}$, and that beyond 30 minutes residual platelet inhibition is less than $20 \%{ }^{49,50}$ Furthermore, the current results with respect to bleeding complications suggest that PGI2 may be advantageous compared with low-dose heparin and that concern regarding prolonged platelet inhibition may be unwarranted. Development of similar agents with shorter duration of action may prove even more effective in accomplishing the dual goals in hemodialysis.

Severe adverse effects would be a serious drawback to the widespread use of an agent such as PGI2. The current experience suggests, however, that although some side effects were more frequent with PGI2, these side effects were seldom severe and did not prevent the use of the agent during hemodialysis. Hypotension was not a particular problem with PGI2 in these studies, although we used only bicarbonate, high-osmolality dialysate as suggested in previous studies. ${ }^{23}$ Fortunately, the aggregation inhibition by PGI2 usually occurs at doses lower than those generally employed in this study and lower than those that generally cause vasodilation. ${ }^{14-16,23,49,50}$ Therefore, if hypotension occurs during hemodialysis with PGI2, doses may be reduced and still retain the antiaggregating effect.

The major adverse event with PGI2 in the current study appeared to be a tendency for increased extracorporeal clotting marked by modest reduction in functional dialyzer volume and by occasional early termination of hemodialysis. Other methods of limiting the bleeding risk, particularly hemodialysis without anticoagulation, have not been-systematically compared to standard low-dose heparin or to PGI2 with respect to extracorporeal clotting and early termination of hemodialysis. In fact, recent uncontrolled hemodialysis experience without anti- coagulant suggests that dialyzer clotting occurs in more than $10 \%$ of treatments, often requires changing of the dialyzer and lines during treatment, and results in average extracorporeal blood loss exceeding $150 \mathrm{~mL} .{ }^{12}$

In conclusion, hemorrhage remains an important and frequent complication of hemodialysis, often exacerbated by the required use of anticoagulants during the procedure. The current study describes the successful use of PGI2, a short-acting antiaggregating agent, in a controlled comparison with standard low-dose heparinization for hemodialysis of patients with increased risk for bleeding. PGI2 was associated with a lower incidence of bleeding complications in the highest risk patients, no serious adverse effects, and only a modest increase in extracorporeal clotting. Based on results of this type, agents such as PGI2 should be considered in patients with serious bleeding risk who require hemodialysis. Furthermore, controlled studies of other methods, new agents, or new devices are warranted in an effort to improve the safety and effectiveness of hemodialysis in the acute, high-risk setting.

The current study was supported by a grant from Burroughs Wellcome Co., Research Triangle Park, NC. The authors acknowledge the participation of the following investigators in the U. S. Prostacyclin Study Group: Richard J. Foley, MD, and Catherine Thompson, MD, Hermann Hospital, Houston, TX; Douglas M. Landwehr, MD, Medical College of Virginia, Richmond, VA; Franklin McDonald, MD, Hutzel Hospital, Detroit, MI; and David Windus, MD, Barnes Hospital, St. Louis, MO.

\section{REFERENCES}

1. Willimann $P$, Alig A, Binswanger U: Minimal intermittent heparinization during hemodialysis. Nephron 1973;23:191-193.

2. Gotch FA, Keen ML: Precise control of minimal heparinization for high bleeding risk hemodialysis. Trans Am Soc Artif Int Org 1977;23:168-175.

3. Farrell PC, Ward RA, Schindhelm K, Gotch FA: Precise anticoagulation for routine hemodialysis. J Lab Clin Med 1978;92:164176.

4. Vogel GE, Kopp KF: The conflict between anticoagulation and hemostasis during hemodialysis. Int J Artif Org 1978;1:181-186.

5. Swartz RD: Hemorrhage during high-risk hemodialysis using controlled heparinization. Nephron 1981;28:65-69.

6. Maher JF, Lapierre L, Schreiner GE, et al: Regional heparinization for hemodialysis. New Engl J Med 1963;268:451-456.

7. Lee JH, Cocke TB, Gonzalez FM: Regional versus "tight" heparinization in hemodialysis. Clin Dial Transpl Forum 1974;4:239246.

8. Swartz RD, Port FK: Preventing hemorrhage in high risk hemodialysis: Regional versus low-dose heparin. Kidney Int 1979;16:513-518.

9. Pinnick RV, Wiegmann TB, Diederich DA: Regional citrate anticoagulation for hemodialysis in the patient at high risk for bleeding. N Engl J Med 1983;308:258-261.

10. Raja R, Kramer M, Rosenbaum JL, et al: Hemodialysis without 
heparin infusion using the Cordis Dow 3500 hollow fiber. Artif Org 1981;5(suppl 58).

11. Ivanovich P, Xu CG, Kwaan HC, Hathiwala S: Studies of coagulation and platelet function in heparin-free hemodialysis. Nephron 1983;33:116-120.

12. Sanders PW, Taylor $H$, Curtis JJ: Hemodialysis without anticoagulation. Am J Kidney Dis 1985;5:32-35.

13. Casati $S$, Moia M, Graziani G, et al: Hemodialysis without anticoagulants: efficiency and hemostatic aspects. Clin Nephrol 1984;21:102-105.

14. Gryglewski RJ, Szczeklik A, Nizankowski R: Antiplatelet action of intravenous infusion of prostacyclin in man. Thromb Res 1978;13:153-163.

15. OGrady J, Warrington S, Moti MJ: Effects of intravenous infusion of prostacyclin in man. Prostaglandins 1980;19:319-332.

16. Zusman RM, Crow JW, Cato AE, Tolkoff-Rubin N: Effects of prostacyclin infusion in uremic patients. Clin Pharm Ther 1981;30:251-257.

17. Dubrow A, Flamenbaum W, Mittman N, et al: Safety and efficacy of epoprostenol versus heparin in hemodialysis. Trans Am Soc Artif Int Org 1984;30:52-54.

18. Addonizio VP, Macarak EJ, Nicolaou KC, et al: Effects of prostacyclin and albumin on platelet loss during in vitro simulation of extracorporeal circulation. Blood 1979;53:1033-1042.

19. Radegran K, Papaconstantinou C: Prostacyclin infusion during cardiopulmonary bypass in man. Thromb Res 1980;19:267270.

20. Longmore DB, Bennett JG, Hoyle PM, et al: Prostacyclin administration during cardiopulmonary bypass in man. Lancet 1981;1:800-804.

21. Woods HF, Ash G, Weston MJ, et al: Prostacyclin can replace heparin in haemodialysis in dogs. Lancet 1978;2:1075-1077.

22. Turney JH, Williams LC, Fewell MR, et al: Platelet protection and heparin sparing with prostacyclin during regular dialysis therapy. Lancet 1980;2:219-222.

23. Smith MC, Danviriyasup K, Crow JW, et al: Prostacyclin substitution for heparin in long-term hemodialysis. Am J Med 1982;73:669-678.

24. Turney JH, Dodd NJ, Weston MJ: Prostacyclin in extracorporeal circulations. Lancet 1981;1:1101-1102.

25. Zusman RM, Rubin RH, Cato AE, et al: Hemodialysis using prostacyclin instead of heparin as the sole antithrombotic agent. N Engl J Med 1981;304:934-939.

26. Hory B, Saint-Hiller Y, Perol JC: Prostacyclin as the sole antithrombotic agent for acute renal failure hemodialysis. Nephron 1983;33:71-78.

27. Remuzzi G: Prevention and therapeutic management of bleeding in dialysis patients, in Nissenson AR, Fine RN (eds): Dialysis Therapy. Philadelphia, Hanley and Belfus, Inc, 1986; 94-96.

28. Talalla A, Halbrook $H$, Barbour BH, Kurze T: Subdural hematoma associated with long term hemodialysis for chronic renal disease. JAMA 1970;212:1847-1849.

29. Milutinovich J, Follette WC, Scribner BH, et al: Spontaneous retroperitoneal bleeding in patients on chronic hemodialysis. Ann Intern Med 1977;86:189-192.

30. Alfrey AC, Goss JE, Ogden DA, et al: Uremic hemopericardium. Amer J Med 1968;45:391-400.

31. Ellison RT, Corrao WM, Fox MJ, Braman SS: Spontaneous mediastinal hemorrhage in patients on chronic hemodialysis. Ann Intern Med 1981;95:704-706.

32. Slusher MM, Hamilton RW: Spontaneous hyphema during hemodialysis. N Engl J Med 1975;293:561-562.

33. Case Records of the Massachusetts General Hospital. N Engl J Med 1982;306:975-984.

34. Borra S, Kleinfeld M: Subcapsular liver hematomas in a patient on chronic hemodialysis. Ann Intern Med 1980;93:574-575. 35. Bleumle LW, Webster GD, Elkinton JR: Acute tubular necrosis. Arch Intern Med 1959;104:180-197.

36. Kleinknecht $D$, Jungers $P$, Chanard J, et al: Factors influencing immediate prognosis in acute renal failure with special reference to prophylactic hemodialysis. Kidney Int 1972;1:190-196.

37. Lordon RE, Burton JR: Post-traumatic renal failure in military personnel in Southeast Asia. Am J Med 1972;53:137-147.

38. Kennedy AC, Burton JA, Luke RG, et al: Factors affecting the prognosis in acute renal failure. $Q$ J Med 1973;42:73-86.

39. Conger JD: A controlled trial of prophylactic dialysis in posttraumatic acute renal failure. J Trauma 1975;15:1056-1063.

40. Vicks SL, Gross ML, Schmitt GW: Massive hemorrhage due to hemodialysis associated thrombocytopenia. Am J Nephrol 1983;3:30-33.

41. Hampers CL, Balufox MD, Merrill JP: Anticoagulation rebound after hemodialysis. N Engl J Med 1966;275:776-778.

42. Merrill EW, Salzmann EW, Wong PSL, et al: Polyvinyl alcohol-heparin hydrogel. J Appl Physiol 1970;29:723-730.

43. Lagergren MR, Eriksson JC: Plastics with a stable surface monolayer of crosslinked heparin. Trans Am Soc Artif Int Org 1971;17:10-16.

44. Holland FF, Gidden HE, Mason RG, Klein E: Thrombogenicity of heparin-bound DEAE cellulose hemodialysis membranes. J Am Soc Artif Int Org 1978;1:24-36.

45. Eberhart RC: Progress in thromboresistant materials research. J Am Soc Artif Int Org 1983;6:45-56.

46. Kim SW, Ebert CD, Lin JY, McRea JC: Nonthrombogenic polymers. J Am Soc Artif Int Org 1983;6:76-87.

47. Klein MD, Drongowski RA, Linhardt KJ, et al: Heparinase: In vivo activity and immunogenicity in rabbits. J Lab Clin Med 1983;102:828-837.

48. Sanders PW, Curtiss JJ: Management of anticoagulation for hemodialysis, in Nissenson AR, Fine RN (eds): Dialysis Therapy. Philadelphia, Hanley and Belfus, Inc, 1986; 39-41.

49. Ubatuba FB, Moncada S, Vane JR: The effect of prostacyclin on platelet behavior. Thromb Haemost 1979;41:425-435.

50. Czer GT, Moser KM: Dissociation between hemodynamic and platelet antiaggregant effects of prostacyclin in dogs determined with a rapid platelet isolation technique. J Lab Clin Med 1983;102:133-139. 